\title{
THEORETICAL ASPECTS OF HUMAN CAPITAL FORMATION THROUGH HUMAN POTENTIAL MIGRATION REDISTRIBUTION AND INVESTMENT PROCESS
}

\author{
Olha PODRA (1) ${ }^{*}$, Liliia KURII ${ }^{2}$, Victor ALKEMA ${ }^{3}$, Halyna LEVKIV ${ }^{4}$, Oleh DOROSH ${ }^{5}$ \\ 1. ${ }^{4}$ Faculty of Management and Economic Security, Lviv State University of Internal Affairs, Ukraine \\ ${ }^{2}$ Scientific department, Khmelnytskyi National University, Ukraine \\ ${ }^{3}$ Department of Managerial Technologies, KROK University, Ukraine \\ ${ }^{5}$ Department of Foreign Economic and Customs Activity, Lviv Polytechnik National University, Ukraine
}

Received 14 September 2019; accepted 15 November 2019

\begin{abstract}
Our research is devoted to the investigation of theoretical aspects of human capital formation through human potential migration redistribution and investment process. This topic was chosen because in the modern conditions human potential development becomes one of basic factors of the competitiveness and economic growing of countries. Migration redistribution becomes an effective mean of indemnification of human potential losses, gives additional possibilities to its development financing, quantitative increase and additional innovative changes in the context of information society and knowledge-based economy development. The detailed analysis of the human potential development and implementation on the global labor market, the emergence of the migration cycle, and process of human potential transformation to capital that is able to provide the socio-economic and individual effects receiving was conducted in the article. Results of this study have theoretical and practical significance. They can be used as a basis for further scientific studies in this field and can be used by state institution in the direction of strategic management of human resources through the human potential migration redistribution and investment process that implies expansion of investment instruments, market infrastructure subjects development all this may provide the reception of material or status effects as a result of human potential capitalization in the labour market.
\end{abstract}

Keywords: human potential, migration, human capital, investments, information society development.

JEL Classification: J24, J20, G61, G62.

\section{Introduction}

Topic relevance. The unevenness of the demographic transition and economic development of the countries creates imbalances in labor markets which lead to the impossibility of human potential effective implementation within national economies. At the same time in the context of the knowledge economy and the information society rapid development there is a growing highly skilled workers shortage of which individual countries are inclined to cover by their migration attraction policies in order to save money and time on the formation of the necessary human potential. In this context, it is obvious that there is an objective bilateral impact of the demographic dimension of globalization and the transition to a knowledge economy on the current course of migration, the redistribution of human potential among countries of the world, becoming uncontrolled. The gradual transition by all countries of the world to the mode of the population reproduction involving simple replacement of generations contributes to the potential loss of the demographic factor influence on the formation of volumes and directions of migration flows. At the same time, the development of the educational and qualification component of human potential as the key resource of the new economy and the main factor of its transformation into human capital becomes crucial. Due to the expansion of the concept of human capital and updating its role in the formation of the information society, the attention of Ukrainian scientists to the peculiarities of the formation and reproduction of human capital, determining its contribution to the formation of competitive advantages, achievement of economic and social effects is increasing. Research of human capital as a factor of knowledge economy formation on the basis of

${ }^{*}$ Corresponding author. E-mail: podra_olha@ukr.net 
intellectual and innovative development is conducted in works Vovkanych, Semiv (2007), Fedulova (2008), Azhazha (2008). The human capital impact determination on economic growth and increasing the competitiveness of the state, enterprise is researched in scientific works of Radionova (2009), Proshak (2008), Dewi, Dwiatmadja, Suharti (2019). Zakharova (2010), Azhazha (2008), Podra (2019) devoted their research works to the study of peculiarities of investing in human capital.

The need to rethink the significance of human capital as the dominant factor in production and the factor of transition to the information society requires a systematic study of the processes and patterns of its formation and the deep theoretical and methodological substantiation. Undeniable is the fact of the completion of agrarian and industrial social formations, the gradual transition to the information society characterized by the development of economic relations on the basis of the comprehensive use of information and human capital as an asset of economic entities, a factor in ensuring the innovative and competitive development of the state, satisfaction of material, moral and status motives of individuals. At the same time we need to state the negative situation with the volume of external labor migration in Ukraine, which is becoming the main reason for the steady population decline, and a threat not only to the development of human capital, but also to national security (gov.ua, 2017). According to the United Nations Population Department (Migration and remittances Factbook, 2011), 6.6 million Ukrainians live abroad but according to informal data 9 million. In this view, the necessity and regularity of the study of the human capital effective formation, development and preservation which provokes the emergence of economic and synergistic effects becomes an actual research.

The object of the article - the process of human capital formation through human potential migration redistribution and investment process.

The purpose of this article is to investigate the process of human potential migration redistribution and it influence on the countries, to research the peculiarities of human potential transformation to a human capital on the investment basis under conditions of information society and knowledge economy formation.

The research methods include comparative and systematic literature analysis, own research conclusions.

\section{Literature review}

The progress of the human development concept is reflected in scientific works of Becker (1993), Schultz (1971), Mincer (1974), Sen (1999). General theoretical issues of international migration and its impact on the economy are analyzed in the studies of Abella (1997), Bohning (1977), Bhagwati (1998), Walmsley, Winters (2000), Desai, Kapur, Mchale (2003), Katseli, Lucas, and Xenogiani (2006), Massey (1998), Papademetriou, Sumption, and Somerville (2009), Simon (1990), Stark (1991), Taylor (1996). In the scientific literature, there is no uniform approach to the study of migration and human development in interconnection, there is no definition of human potential reallocation by migration, not enough attention is paid to the development of mechanisms for the effective human potential implementation and its transformation to the form of human capital.

However, some studies highlight migration as a tool to establish horizontal social structures (networks) based on reciprocity, continuous information exchange and create trust among their members. Such networks become a basis for social capital formation (Sciavo-Campo \& Sundaram Pachampet, 2001). As mentioned by Putnam (2000), social capital provides the spreading of essential information for more efficient implementation of human potential and transforming it into human capital.

Other scientists speculate on "circular migration" as a long-term, flexible model of international human mobility emerging from the shared economic space resulting from globalization, and provides the most profound implementation of human potential (Agunias, 2016). Several types of research prove the shared economic benefits of this prevailing type of migration between the countries of origin and destination. In spite of this, the population sometimes has a negative attitude to migration because of its cost, that is, an additional burden on the social assistance system, which is often used by migrants, increasing the burden on education, transport, and housing. However, as a result, migrants work off these costs and generate additional income for the host country, as well as for the destination country through the remittances (Geddes, 2005; Migration and remittances Factbook, 2011). For example, investing in the human capital of migrants by special expenses on migration administration (resettlement, integration and language courses, adaptation to the labor market, retraining, medical expenses, etc.) always result in the GDP increase. The forecasts of the Former European Commission Advisor Ph. Legrain estimates EU spending on humanitarian migrant management to reach $€ 69$ bn by 2020, while total EU GDP growth will increase by $€ 126$ bn (Legrain, 2016).

A group of world leaders belonging to the Club of Rome believes that it is international migration that enables people to make their choice in favor of realizing their potential in the face of deep social inequality, the destruction of states, military and civil conflicts, economic crises and unemployment (The club of Rome, 2018; Capitalism, Short-terminism, Population and the Destruction of the Planet, 2018).

Europe 2020 A Strategy for Smart, Sustainable and Inclusive Growth identified measures by which EU countries would be able to achieve a lasting and long-term improvement in the quality of life through the formation of sustainable communities capable of enhancing the social and innovation potential of the economy. The integration of migration networks and investing in the human capital of migrants are inevitable stages in this process (Europa 2020, 2010; Kraay, 2018). 
The investments in human capital have a great influence on the economic growth, stability and effects obtaining, so there is a need to determine the impact of the scale of labor migration and remigration to the present and future state of human capital. Investing in the development of human capital is an urgent research topic of a number of scientists. Formation and development of human capital theory, efficacy of investment in this asset was initially described in the scientific studies of Becker (1993), Kendrick (1976), Schultz (1971), Solow (1990), Thurow (1970), and others. The basic provisions concerning human capital are reflected in the works of List and Rasul (2010), and others. Several authors came to the concussion that factors affecting human capital formation and quality have a steady relation to education, health, science, personal security, business climate, informational support for work as well as culture (Pekar, 2012, Corejova \& Kassiri, 2016; Gladka \& Fedorova, 2019). The scientists of International Organization for Migration in Ukraine (IOM, 2016) try to work out approaches to the better use of human, social and financial capital of migrant for providing the long-term development of Ukraine, at the same time they point out that that in current Ukrainian realities, labor migration as a factor of human capital is, in fact, a survival mechanism in the fight against poverty or avoiding unemployment.

Nevertheless, a number of theoretical, methodologi$\mathrm{cal}$, and practical issues remain unresolved due to unsystematic and sporadic research, identification of related concepts, the complexity of the investments effectiveness measurement as a result of the human capital dual nature, the imperfections of the legal framework for the settlement of the human capital reproduction and implementation system, investment instruments, intellectual property rights, copyright and related rights protection, slowdown in information society development due to the existence of technical and educational barriers, and the lack of an effective mechanism of investment in human capital, taking into account factors of the information society development and migration tendencies. These and other circumstances determine the relevance of the research topic and the need to consider the significance of human capital formation through human potential migration redistribution and investment process.

\section{Study background: human potential migration redistribution}

At the current stage in the information society, the realization of human potential implies the need to constantly acquire and update knowledge. The lack of the possibility of implementing this principle in the national economy as well as the other two basic principles of human development (to live a long and healthy life and to have access to resources to ensure a decent standard of living), necessitates the redistribution of human resources by migration in the global economy for optimal implementation
Therefore, it is necessary to consider the human potential of the migrant as a part of the nationwide human potential.

It should be emphasized that as a result of migration the human potential of a migrant is redistributed between the country of origin and destination.

On the one hand, the share of human potential can be lost for both countries; on the other hand, migration redistribution creates ways to increase it. In this case, the human potential of a migrant can be implemented in both countries, regardless of the place of residence of the person, creating benefits for both parties. Thus, migratory redistribution of human potential involves the migration of the population as a carrier of abilities, talent, knowledge, a certain level of education and qualification, physical and mental health, intellectual development within the world economy in search of better living conditions and employment in accordance with economic laws.

The basis of the human potential migration redistribution lies in the distribution of its components with the help of various types of migration. Each of the components can change the conditions of its implementation in time through permanent, temporary, seasonal or pendulum migration and the place of implementation in the direction of emigration, immigration, re-migration or circular migration, and to acquire voluntary and compulsory, legal and illegal forms of movement. The qualitative composition of human potential, namely its educational and qualification component provides its redistribution in the form of an international movement of highly skilled, low skilled and semi-skilled workers, and thus brings the constant changes to the international labor market (Figure 1).

The functioning of the global labor market contributes to the realization of human potential in those national economies, where there are appropriate opportunities for remuneration, acquisition, and updating of knowledge, professional growth, levels of social protection and quality of life. Migrants are directly benefiting from access to higher wages and better living conditions with the subsequent transfer of these benefits to their families in national economies through remittances, the global volume of which in 2016 was $\$ 536.7$ billion.

The distribution of each component of human potential in the form of a particular type of migration leads to concrete consequences that can acquire positive or negative value for origin and destination countries.

For example, the redistribution of the educational and qualification component of human potential through temporary voluntary legal emigration of skilled workers is manifested in increasing the economic, intellectual and labor potential and, at the same time, increasing tension in the domestic labor market, the need for additional financial costs for adaptation and integration in destination countries; loss of labor, intellectual, educational and qualification potential and, at the same time, improvement of socioeconomic, innovative and educational conditions for the human development in the countries of origin. 
In accordance with the consequences, in order to increase their positive effect and reduce the negative, the objectives of migration redistribution are being formed for the implementation of which specific tools are applied. The use of these tools provides the general results of human development through migration. For example, the growth of income and the receipt of investment resources by the origin country due to the flow of remittances causes the need to stimulate and regulate these flows through economic reforms and bilateral agreements with the countries of destination that contributes to the increase of human development indicators and reduced readiness to migrate due to the improvement of the economic situation.

Figure 1 confirms a general idea that countries of destination prefer immigrants who are professionals giving them permission for permanent residence and a simplified procedure for entry for highly skilled workers - people who are able to accumulate and use knowledge efficiently. Their position is a legitimate response to the growth of migration in terms of the intensive development of the knowledge economy and the transition to the information society where human knowledge is the main productive force.

Analysis of human potential components and the consequences of their migration redistribution points to the predominant role of the demographic and educational and qualification factor in the human potential formation. Separating the main types of migration in time and qualitative composition allows to trace the effect of migratory redistribution of demographic and educational and qualification components of human potential and the emergence of migration circuit due to the increase of the countries migration attractiveness on the basis of the increase in human development indicators. Permanent migration of low skilled workers mainly affects the demographic composition of human potential in destination countries. Migration of semi-skilled and highly skilled workers on a permanent basis contributes to the formation of the educational and qualification component of human potential and its qualitative improvement in the countries of origin and destination through the transfer of knowledge, experience, and financial resources. Temporary migration of semi-skilled and low-skilled workers provides the satisfaction of the current labor market needs of destination countries (Figure 2).

According to the Figure 2, re-emigration contributes to improving the quality of human potential and creates prerequisites for the transformation of local industries, implementation of organizational and technological innovation. The concentration of intellectual human potential in a region ensures economic development and growth and thus creates opportunities for the realization of its other components demographic, life, social. Expansion of production in areas of innovation and subsequent job creation determines as a result flows of low and medium skilled workers. The development of the US economy where innovation progress contributes to economic growth stimulating the flow of low- and the medium-skilled workforce is a vivid example. Innovative development, in turn, increases the economic potential of the region including the technological level of production, the availability of modern equipment and technology. The development of the economic potential contributes to increasing indicators of human development and therefore migration attractiveness thus stimulating new migratory flows. In this regard, the main areas of the relationship between migration and human development in countries of origin and destination are to be explored and highlighted and special regulations should be identified.

Cyclical and temporary migration of highly skilled workers through the formation of educational and qualification component of human potential create conditions for its development in the countries of destination and origin through remigration of highly skilled professionals, returning students (accumulation of knowledge), creation of educational, research and scientific networks, forming

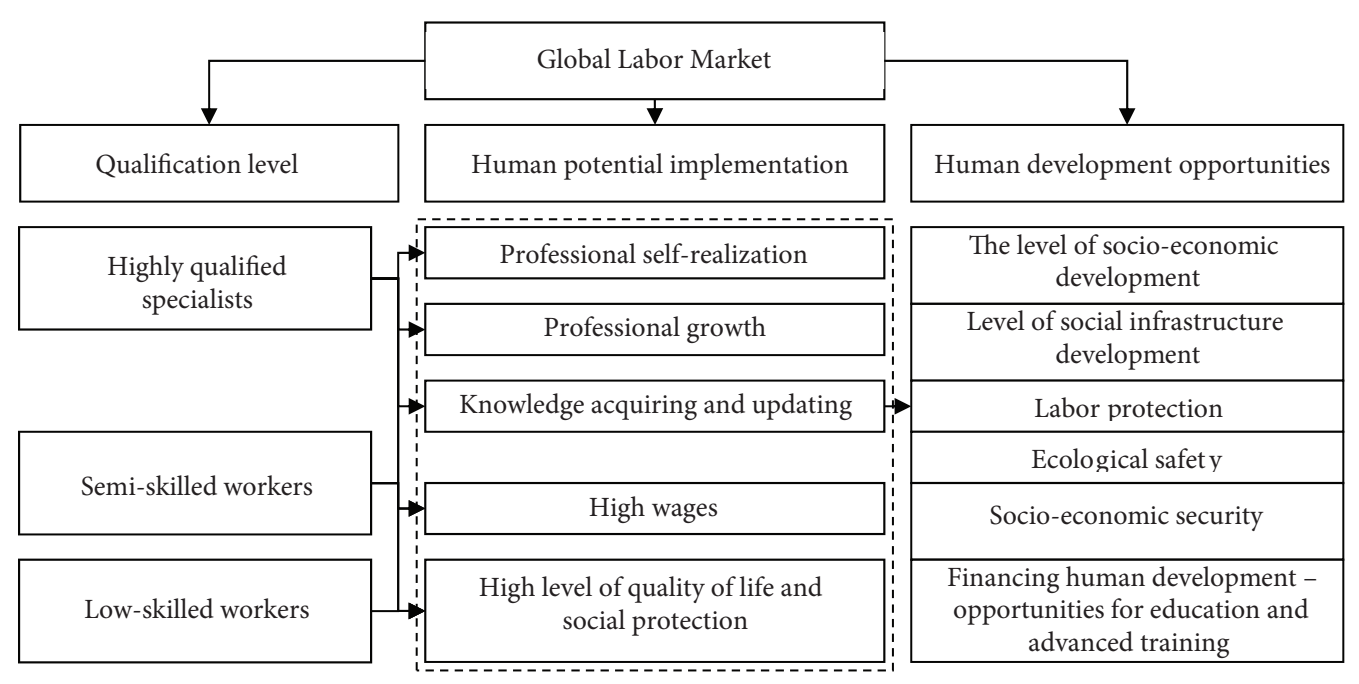

Figure 1. Implementation of human potential on the global labor market (worked out by authors) 
social communities (innovation advantages in management decisions, business organization and administration and social activity). These positive trends, in turn, lead to improvement in human development indicators and, consequently, increase their migratory attractiveness which helps attract new migration flows. Thus, the human potential redistribution creates conditions for the existence of the migration cycle.

The systematization of modern migration relationship allows identifying characteristic and objective patterns of human potential redistribution in the global economic system. We may conclude that the world's centers of innovation in modern conditions of information society and knowledge economy rapid development are both centers of gravity of international migrants. An example is the countries of Southeast Asia, which have created large-scale technological centers in their own territory. In India, the formation of the center of intensive technology Bangalore has contributed to the involvement of more than 250 thousand specialists since 2000 (Jain, 2013).

The intensive development of the region is characterized by a significant degree of clusterization that is the close relationship between research institutes and hightech branches of electronics, telecommunications, defense industry and engineering which interact with a significant number of small and medium enterprises. The system of knowledge production includes scientific institutions specializing in theoretical and fundamental research - universities, higher schools, research centers and laboratories which carry out $60-80 \%$ of all fundamental research in the country (Zand, 2000).

The innovative structure of a cluster ensures high efficiency of production and creation of new workplaces.
Such an environment enables the implementation of human potential by specialists of different qualifications: professional self-realization, professional growth, acquisition and updating of knowledge, high level of remuneration. Trends in human potential displacement to the fields of innovation activity, services, management and education in the structures of national economies provide an opportunity to assume an increasing role of migration policy in the foreign economic activity of the countries as an important means of attracting the necessary resource for economic development. The main factors of migration in such conditions are economic and intellectual-professional.

The concentration of intellectual human potential in a certain region guarantees economic development and growth and thus creates opportunities for the implementation of its other components: demographic, life, social. As a result, the expansion of production in innovative zones, the creation of new jobs result in migratory flows of low skilled and semi-skilled workers. Innovative development, in turn, increases the economic potential of the region, which includes the material and technical level of production, the availability of the latest equipment and technologies. The development of economic potential leads to an increase in the indicators of human development, and hence of migration attractiveness, thus contributing to new migration flows.

It should be noted that in the pre-crisis period, the amount of cash in Ukraine was significantly higher. For example, only in $2007-21.3$ billion dollars. The US, which was $24 \%$ of the country's GDP (in $2018-10 \%$ of GDP). Despite this, two thirds of the money received from labor migrants is spent on domestic needs, the rest - on starting

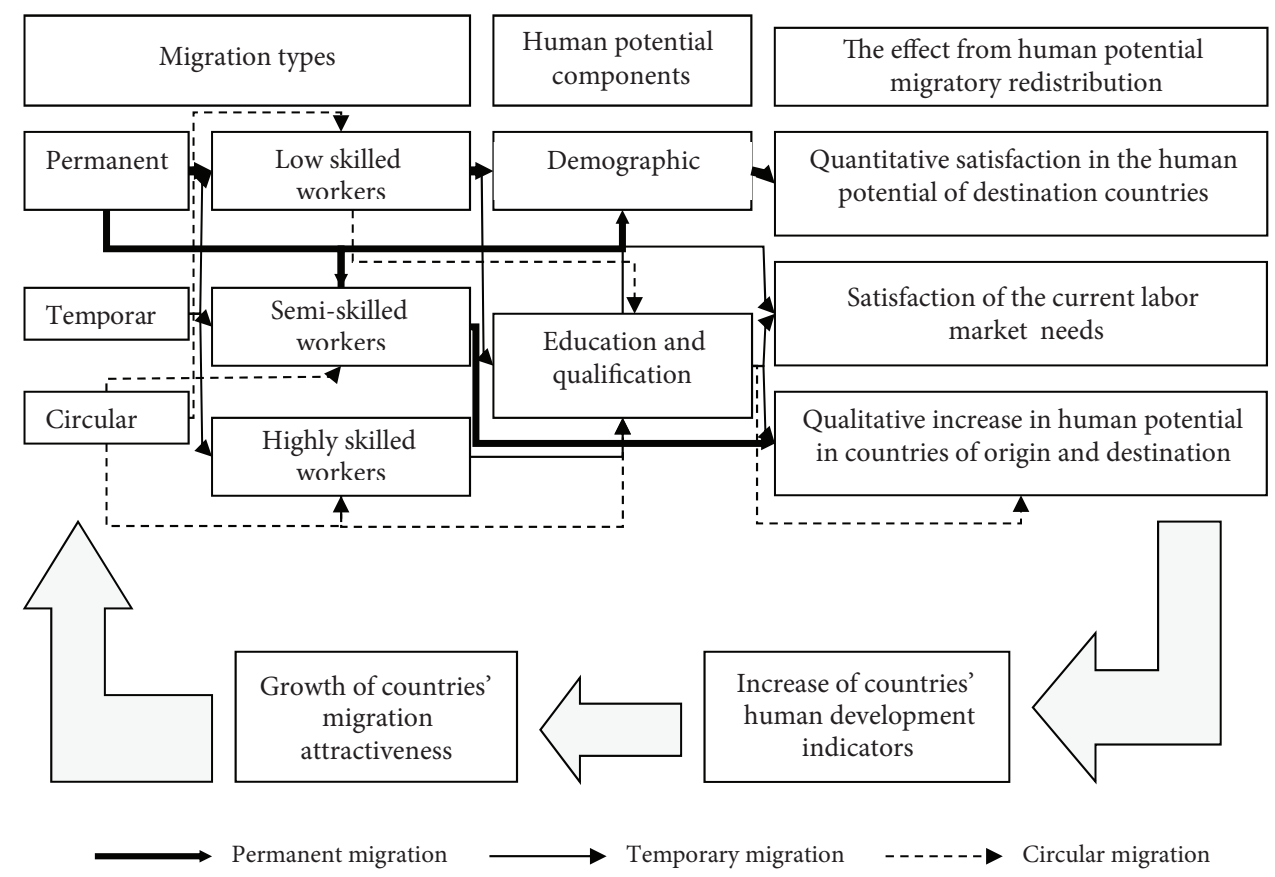

Figure 2. The relationship of the main types of migration and human potential components in the context of its rational redistribution and the emergence of the migration cycle (worked out by authors) 
their own business, creating new jobs, and developing the economy International organization for migration (2016). In addition, the high rate of inflation that is generated impedes the formation of a favorable investment environment in the financial sector and reduces the incomes of the population and their purchasing power. In its turn, the country is experiencing a slowdown in the process of modernizing the national economy, violating macroeconomic stabilization and slowing down socio-economic development.

One of the key global processes now is the intellectual redistribution of the world which means competition between countries for possession of the most competitive global resource - human intelligence, namely the possession of modern knowledge carriers and the creators of the latest techniques, technology, and culture. Human capital is becoming a determining factor in competitiveness, the basis of intellectual and social capital as a condition for economic progress. Against the background of the growing importance of human capital as a leading resource, fundamentally different economic and industrial relations are associated with the growth of the mobility of population in the global dimension. Migration processes have a significant impact on the formation, maintenance, and capitalization of human potential of any country, so it is extremely important within our research to determine the positive impact of mobility in the context of investment in human capital.

\section{Research methodology}

At the current stage of the economic science development, methodological approaches have been developed to evaluate the investment in human capital both at micro and macro levels. According to traditional provisions, investment in human capital is considered to be efficient for a high level of profitability and a short payback period. In view of this, the question of assessing economic efficiency remains relevant in the current economic realities of the of the information society rapid development.

The founders of the investment in human capital theory linked its growth with the accumulation of capital in the sphere of education, and the effectiveness of its reproduction and application related to the development of education. For the determination of the rate of return on investment in education it can be used the standard function of wages. Human capital value is evaluated as a capitalized rent which means the supplement to the earnings that gives an education.

In our opinion, the efficiency of investments in human capital can be considered in two main categories:

- firstly, through the economic efficiency which involves an increase in an individual income and an enterprise profit, an increase in labor productivity;

- secondly, the socioeconomic efficiency which is expressed in the growth of the level and quality of life, reduction of the social stratification by property and social status, the possibility of self-realization, etc.
At this stage of the study, it should be concluded that the definition of the investment effectiveness at the individual and the entity levels are developed sufficiently, while the state's effects from this process are difficult to assess and in most cases are social in nature. At the same time, one should not underestimate the economic effects of GDP growth on the basis of income and consumption growth which is due to the accumulation of qualitative characteristics of human capital and the growth of labor productivity on their basis. Consequently, we can conclude that the state's investments in education, health care, science, spiritual and cultural development contribute to the emergence of a multiplier effect. Therefore, in our opinion, it is expedient to introduce the coefficient of public investment contribution in human capital which should be determined by the ratio of the total amount of public investment in human capital to the sum of these investments with investments in fixed assets:

$$
C s i=\frac{T s i_{H C}}{T s i_{H C}+I_{F A}},
$$

where $C_{s i}$ is the coefficient of state investments; $T s i_{H C}$ is the total state investments in the development of human capital; $I_{F A}$ is the investment in fixed assets.

On the basis of the indicated coefficient, we can determine the multiplicative effect of public investment in the human capital using the following formula:

$$
E m=\frac{G D P_{g r}}{T s i_{H C}+I_{F A}} \times C s i,
$$

where $E_{m}$ is a multiplier effect of state investments; $G D P_{g r}$ is a growth of $G D P$.

The main goal of the state in investing in human capital is to increase the level and quality of education, health, mobility, awareness of the population, the growth of intellectual capital, establishing the preconditions for sustainable economic development. Today the three-dimensional concept of sustainable development is relevant the components of which are economic, social and ecological. Therefore, by investing in human capital the state plans to get at least three types of effects: economic, social, and environmental.

The models of human capital impact on economic growth are widely used in international practice. The state invests in human capital in two general cases. Firstly, through a system of training specialists needed by the public, but not demanded in the labor market, for example, social workers, ecology workers, etc. Secondly, the state is investing in the training of specialists in accordance with the demand conditions in the labor market or according to sound forecasts. Thus, the state also has investment risks.

From the analysis, we can conclude that the migration redistribution of human potential contributes to the implementation of its constituent elements, and thus provides a transformation into human capital that can bring socioeconomic and individual effects in the case of an effective investment process. 


\section{The peculiarities of human capital formation under condition of information society development and knowledge-based economy formation}

In most cases person's activity is directed on the human potential recreation on the basis knowledge enlargement without understanding an essence of individual asset, which is able to create an additional profit and provide the receipt of competitive edges at the labor market and social status achievement.

Only the subjects of economic activity are oriented to the human capital management, provide the converting (transformation) of a human potential to a human capital, on the basis of selective choice of necessary components, provide human capital investment reproduction, with the purpose to get an additional business-asset on the basis of which to achieve the productivity and competitiveness increase effects, economic activity efficiency and innovative activity increase, to do further periodic in-plant training under conditions of technical, technological and innovative development growth with the purpose to provide market abilities increase for more difficult economic processes realization and human capital loss risk diminishing.

Such understanding of human capital has a principle value, because gives an opportunity to examine it as a proof and constantly reproduced economic phenomenon that is incarnate in people. At the same time individual human capital is a base for human capital of subjects of economic activity and state.

In our opinion, productive capabilities, experience, abilities are capital not only because able to generate the future streams of profits and not because are performed due to reducing of current consumption, but because can provide possibility of profit earning as a result of implementation in economic activity. For this reason human capital becomes the factor of production, which brings a profit (income) as a result of the effective use of knowledge, skills, experience, mobility which was received as a result of investments of the basic subjects.

Increased productive abilities of employee become his property - an individual human capital. At the same time, in a labor activity (labor market) the worker offers own labor force and at the same time owns the greatly increased human capital as a result of previous investment made into own intellectual development. Therefore, if the worker remains in hiring, then he will gain income from own human capital partially as he is in exploitation of the employer who is also interested in receipt of an additional income, in other case, the carrier of a human capital can act as the independent entrepreneur, the producer, the owner and the manager of intellectual property and to gain income in full. More often we can observe an equation of human capital with a term human potential because of general sources of their formation and development. However, human capital - it is only part of human potential which transforms into an asset as a result of plugging in labour activity and its separate components capitalizations, that allows to get the planned effects.

Complication of essence of "human capital" concept raises a problem of a category mess and frequent equation with contiguous concepts that is why we offer to consider and define differences between them.

Thus, human capital differs from previous economic categories that is not only characterizing individual potential capacities in labour or enterprise activity realization, but determines the real productive capabilities use which provides possibility of additional earnings or profit reception.

This capital is the unique among other resources, which has update, perfected, develop ability. At the same time, in the conditions of information society formation the human capital needs to be considered from the point of view of investment concepts as the asset which is created on the basis of investments and brings income during the inclusion in economic activity, promotes achievement of effects.

On a basis of the above made arguments, we offer own determination of a human capital - it is a component of human potential - the asset which is saved up as a result of private or state investments is characterized by availability of necessary knowledge, skills, abilities, qualifications, professional training, motivation, practical experience, health which are a personal property of the individual and can't be separated from the owner, are implemented in economic activity, promote economic and social efficiency of production, increase national economy competitiveness and at the same time influence growth of a personal income of the person (human capital owner), the entity and society, in general.

Therefore, as a result of the conducted research of evolution of a concept of a human capital, it is arise a new image where the human capital should be considered as an asset. However, not all its components should be considered assets, but only those which bring income in economic activity.

The ability to use and enhance (to increase greatly) individual human potential in economic activity, leads to its transformation into category of an asset due to receipt of the highest (additional) income. Therefore on the one hand the human capital is a set of general education, professional knowledge, abilities, skills, health, experience, professionalism, motivation, and from another it is expenses, capital investment of the state, entity, organization, public funds and the person which directed on formation, obtaining, enhancement and fixed improvement of knowledge and skills.

The human capital (HC) as well as any other type of the asset is a result of investment and accumulation of an income during certain time which will be reinvested in the future in the development and accumulation, that is in receipt of additional knowledge and qualifications. Such investments will pay off in the form of receipt of additional earnings and increase in profit level on the basis of advanced highly skilled and productive work, receipt of moral satisfaction, from the chosen profession. 
As a result of human capital components research in the scientific works of this field, we consider that to its structure it is necessary to include those which directly promote receipt of material, social, moral or status effects taking into account factors, features and conditions of formation. To our opinion, it is necessary to include to human capital such components:

- knowledge, professional capabilities, skills, talents which are created on the basis of such key factors as education, the system of primary, secondary, professional and higher education, self-education, self-improvement, the international exchange and training;

- physiologic and psychological state of a person which forms on the base of natural capabilities, a health care system, an ecological situation in the region, conditions, modes and labor protection, level of living;

- experience, that received in the process of inclusion to economic activity and is characterized by skill level and professionalism;

- motivation, that is characterized by factors of financial and moral incentive, level of needs satisfaction, implementation of career development, social security and guarantees;

- mobility, that is characterized such factors as: labour market development, innovative changes, informational support that concerns labour conditions, modes and compensation, a financial incentive, etc.

We complemented the classification with a component "information mobility" which depends on development of informational and communicational technologies, development of science, fast market environment changes, provides a capability of the person to collect, sort, study, select necessary information in the overflowed informational channels and to use it effectively in the conditions of informational society development.
It should be noted that the human capital acquires special relevance only under conditions of information economy existence which formation started at the end of the XX century and was connected with a crisis of industrial society which main resources were the capital, limited natural resources, raw materials and energy, labor-intensive and capital-intensive technologies. As a result, there was an overproduction crisis as a result of accretion of production capacities and lack of information on consumer tastes and demands, alternative resource sources, transportation (logistic) D. Bell (1993). Also between the main categories of industrial society, information society and knowledgebased economy some differences are exist (Table 1).

The impossibility to rationalize and stabilize production and economic transactions entailed the research of ways of an exit from permanent crises of industrial society on the basis of information providing, that means the development of tools of the information rationalization that provoked development and usage of information technologies which became a stage of a transition to information society.

Information society should be considered the intermediate stage between industrial economy and knowledgebased economy, at the same time, due to its formation there is deviation from the theory of labour recourses to concepts of a human capital. Understanding of a key role of the person and its capabilities in receipt of economic, social and status effects, decrease the industrial sector in production of GDP, growth of value of the IT industry, informatization and a computerization of economic activity, employment increase in service trade and information communication sectors.

Emergence of the information society concept is connected with researches of Machlup (1962) who stated five sectors of information activities: education, research and development, information technologies and services,

Table 1. Differences between the main categories (worked out by authors)

\begin{tabular}{|c|c|c|}
\hline Industrial Society & Information Society & Knowledge-based economy \\
\hline \multicolumn{3}{|c|}{ Human resources } \\
\hline $\begin{array}{l}\text { Manpower (labour resources, work } \\
\text { force) - the person passive object of } \\
\text { management. Prevalence of an industrial } \\
\text { employment }\end{array}$ & $\begin{array}{l}\text { Human capital and information are key } \\
\text { productive forces of information society, } \\
\text { prevalence of employment in service } \\
\text { trade, and in information communication } \\
\text { sectors }\end{array}$ & $\begin{array}{l}\text { Human capital, information and } \\
\text { knowledge are key productive forces of } \\
\text { knowledge-based economy, prevalence } \\
\text { of employment, in the non-productive } \\
\text { sphere, scientific sectors }\end{array}$ \\
\hline \multicolumn{3}{|c|}{ Features of functioning } \\
\hline $\begin{array}{l}\text { The leading sphere of economy is the } \\
\text { industry which development is possible } \\
\text { by an accretion of amounts of usage of } \\
\text { material, labor, natural, financial resources } \\
\text { and on the basis of implementation in } \\
\text { production the achievements of NTP }\end{array}$ & $\begin{array}{l}\text { Growth of value of the IT industry in } \\
\text { economy and information component } \\
\text { in cost value of goods and services, a } \\
\text { computerization and automation of } \\
\text { business processes, change of nature of } \\
\text { work, - growth of creative, individual } \\
\text { activity }\end{array}$ & $\begin{array}{l}\text { Growth of scientific high-tech sectors, } \\
\text { intellectualization of production, } \\
\text { knowledge become the main factor; } \\
\text { change of nature of work - creative } \\
\text { intellectual work on the basis of } \\
\text { implementation of quality life-long } \\
\text { education }\end{array}$ \\
\hline \multicolumn{3}{|c|}{ Factors of investment and development } \\
\hline $\begin{array}{l}\text { Charge basis of a manpower formation, as } \\
\text { a result of their secondary role }\end{array}$ & $\begin{array}{l}\text { Investment base of human capital } \\
\text { formation }\end{array}$ & $\begin{array}{l}\text { Investment base of human capital } \\
\text { formation }\end{array}$ \\
\hline
\end{tabular}


mass media, and scientist determined their part in production of GDP of the USA. D. Bell (1993) researched value of information and knowledge in transition from goods production to services production. The information society used to be considered a society in which growth of information, knowledge, information technologies and industries that creates them is higher in comparison with traditional production of goods and services; such society becomes a source of new workplaces creation and a dominant of economic development. In our opinion to features of information economy it is necessary to include a high degree of dependence of economy on information, increase of IT technologies production, their wide usage in business processes, transformation of information products into goods. It is obvious that with growth of a role of information society it is necessary to determine its key factors (Figure 3).
According to us, it is necessary to divide all factors of information society development in Ukraine at least in four groups:

- technical and technological group means the reorganization of information and communication infrastructure of the country on the basis of enhancement and development of computing resources, stimulation of development of new information, computer and telecommunication technologies for the purpose of ensuring access, transfers, use and confidentiality of information;

- social and economic group provides for state support of producers and consumers of information technologies, products and services, formation of information culture and requirement of the population, stimulation of solvent demand on information products and services;

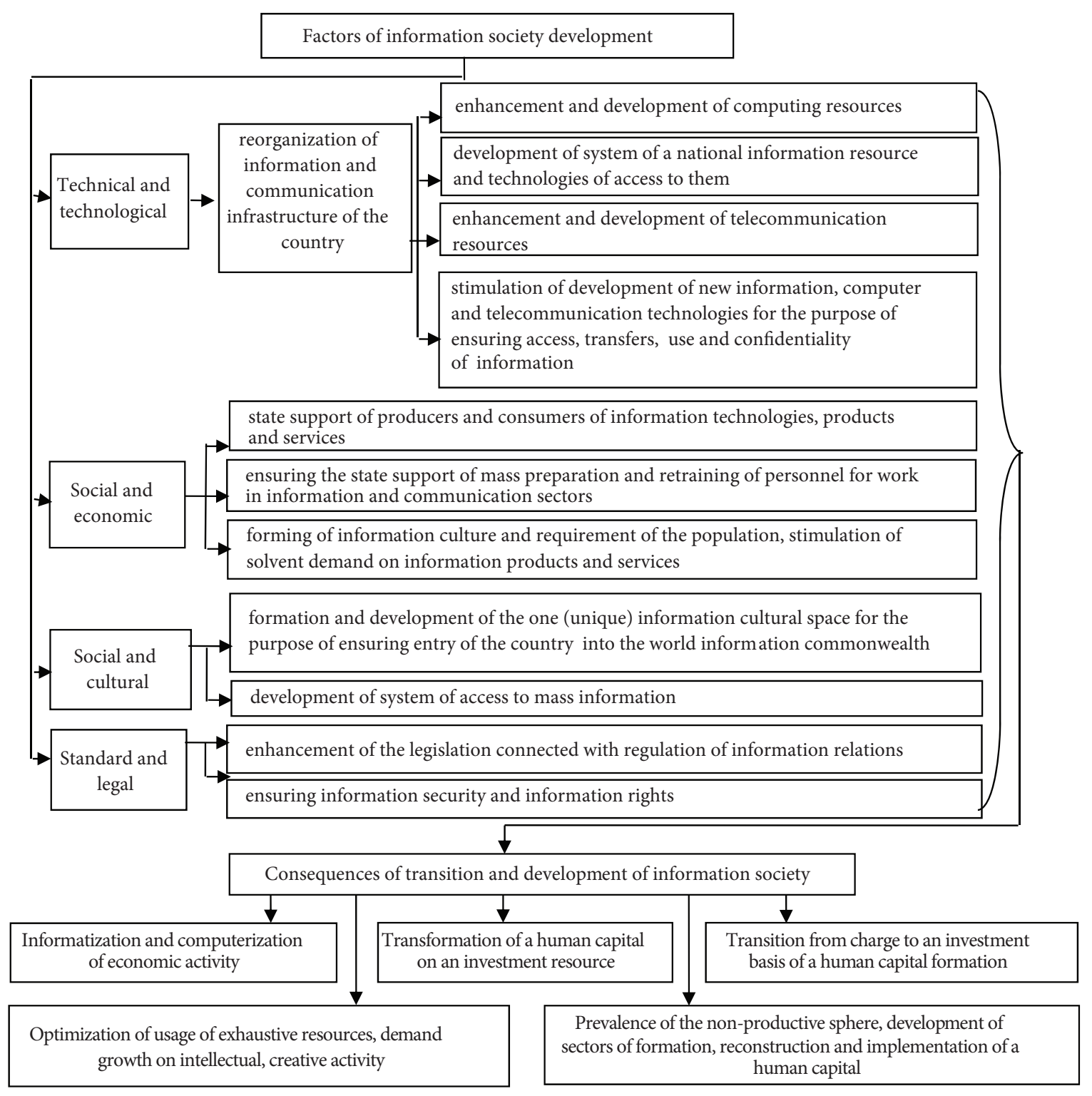

Figure 3. Factors and consequences of information society development (worked out by authors) 
- social and cultural group influence the development of system of access to mass information, formation and development of the one (unique) information cultural space for the purpose of ensuring entry of the country into the world information commonwealth;

- standard and legal group demands the enhancement of the legislation connected with regulation of information relations and ensuring information security and information rights.

When we consider all the factors of information society development in Ukraine, we can predict the consequences of the transition and development of the information society, for example transition from charge to an investment basis of a human capital formation, optimization of usage of exhaustive resources, demand growth on intellectual, creative activity, informatization and computerization of economic activity etc.

According to us, it is necessary to refer to results of development and reorganization of information society such components:

- informatization and computerization of economic activity;

- transformation of a human capital to an investment resource, one of key forces of economic and social development;

- changes in industry structure of economy and employment, growth of a role of sectors of formation, recreation and implementation of a human capital;

- reproduction, integrity, inexhaustibility of information society resources, optimization on their basis the use of exhaustive resources which generates great demand on intellectual, creative activity;

- transition from charge to an investment basis of a human capital formation with the use of new investment instruments.

Therefore, consequences of information economy development appear in a computerization and automation of business processes; a growth in volumes, processing, transfers, storages of information; creation of global information space; change of the status of a manpower transformation to the capital as a result of investment basis formation, and opportunity to gain the planned effects, emergence of new employment forms and employees increase in informational and intellectual spheres. Therefore at a stage of information society development the worker, who is the carrier of a human capital, requires to have a wide amount of knowledge, abilities, skills, experience, skill, to use information that become a guarantee of rationalization of economic processes, financial, investment, social effects achievements, implementations of tactical and strategic objectives of enterprises.

Therefore, development and enhancement of information technologies turns into the certain sector of economy, information support creates competitive advantages and determines the direction of economic activity. At the same time, at late stages of information society development there is an overflow of information channels without receipt of any effects, this is the result of the law of the decreasing return, this law appear when exist a lack of knowledge that concern effective use of information and its transformation on social and economic, investment, technological effects.

At this stage only abilities to apply the information correctly, can provide an exit from permanent crises, becomes a factor of transformation of information society into knowledge-based economy. In a knowledge-based economy knowledge acts as the main productive force of the subsequent development, and the person is the creator and carrier of the knowledge, who develops on the basis of education, science, health care and become a factor of the subsequent development and the capital that will bring income.

For this reason investments in educational process with use of new tools and involvement of new subjects of investments that are able to create highly qualified specialists who have great demand in the labor market are actualized, as a result, fast return on investment, that performed in own education is provided. The knowledgebased economy significantly differs from the previous public formations in the fact that knowledge creates additional value on the basis of intellectualization of technologies which provides labour productivity increase; growth of science intensity of the developed products on the basis of expenses increase in scientific research; development of intellectual goods and services market much faster, than traditional markets.

Due to noted features a key role in knowledge formation is played by education and allied industries which promote development of capabilities of the person concerning production, preserving and usage of knowledge. In knowledge-based economy education is considered as a form of human capital investments on which depends the quality of economy.

\section{Conclusions}

Migration effects can have positive effects on human development. There is a need to find new models of economic and social development in a highly competitive environment, to justify access to global markets and, on that basis, to provide conditions for improving the wellbeing of people. The basic feature of modern migration is that it is a phenomenon that is institutionalized, evolving from a traditional social movement into a structured social organism (diaspora, migrants networks, infrastructure of the migration services market, etc.), and thus into an owner of social and human capital, that is the entity worth investing.

At this stage of the study, it can be concluded that the regulation of migration processes in Ukraine requires the development of a comprehensive, sustainable and flexible migration policy. This policy should be created according to the Ukraine's socio-economic development strategy and global competitiveness increase of the country. The main goals of the implementation of a set of measures of 
migration policy are meeting the educational, qualification and demographic needs in human potential, its preserving, enhancing its qualitative characteristics, efficient usage of human potential for economic growth, and as a result ensuring its capitalization - transformation to human capital - and opportunities to obtain investment effects. At the same time it is necessary to point out that in the course of European integration it is important to bring Ukrainian migration legislation to the European level. Some achievements in this field are demonstrated by the Law of Ukraine "On Foreign Labor Migration" (November 2015, second reading) (The Law of Ukraine "On foreign labour migration"), the adoption of which is conditioned by the need to improve the mechanisms of state regulation in the field of foreign labor migration in accordance with current requirements. The law guarantees additional opportunities for employment abroad, in particular for persons who temporarily worked or still working abroad (migrant workers) and members their families. Legislation on the protection of temporary employment of migrant workers broadens the possibilities of protecting a migrant in the professional field and, consequently, protecting his or her human capital.

An important step in the implementation of the social policy of the state is the practical implementation of legislative mechanisms for returning migrant and educational migrants to Ukraine after a long labor and educational migration. The objective of the state migration policy is to create conditions through the implementation of a set of social, legal and economic measures aimed at ensuring that labor and educational migrants adapt to the socioeconomic life of the country after returning to Ukraine.

The hold research helped to come to a conclusion that human potential mobility like demographic, educational, physiologic is one of key factors of competitiveness of a human capital. At the same time Ukraine's economy, as part of the Eastern European economy, has rapidly undergone a process of integration into the global system of international migration and shadow financial flows. In addition, it was subjected to significant disparities in the world economy, which in the future provoked the emergence of a global financial and economic crisis, and as a result emerged such phenomena as the shadow economy, organized crime, corruption and environmental crime, smuggling, terrorism, "laundering" money, illegal migration and shadow employment. In order to shake up the labor market and to avoid the losses of human capital of Ukraine, it is necessary to: (1) create favorable conditions for the development of entrepreneurship and increase real incomes and their legislative regulation; (2) reduction of tax pressure on entrepreneurship and simultaneous strengthening of liability for crimes connected with tax evasion; (3) improvement of the state policy on the nationalization of the national economy through legalization and decriminalization of illegal employment; (4) stimulation the development of market infrastructure of investment institutes, private investment through credit and tax mechanisms in order to provide investments increase in human capital. As a result, in Ukraine it will be possible to achieve a European level of social protection of the population, timely repayment of debts on external and internal borrowings, and an increase in the country's rating by all indicators in the international arena.

Transition from industrial to information society, and next to the knowledge-based economy provokes change of the status of a labour resources (work force), their exclusive positioning, as a human capital - an asset of enterprises, a factor of innovative and competitive development of the state, a factor of satisfaction of material, moral and status motives of individuals. These arguments show us the necessity and regularity of investment into the person on the basis of education, educational development, and health care, stimulation of extensive and intensive reconstruction and mobility which provokes emergence of economic and synergistic effects.

\section{Author contributions}

The authors contributed equally.

\section{Disclosure statement}

The authors do not have any conflict of interest.

\section{References}

Abella, M. (1997). Sending workers abroad: A manual for lowand middle-income countries. Geneva: International Labour Office.

Agunias. (2016). Circular migration and development: trends, policy routes, and ways forward. Migration Policy Institute. http://www.migrationpolicy.org/pubs/MigDevPB_041807.pdf

Azhazha, M. A. (2008). Intellectualization of the economy: innovation and human potential in the conditions of globalization. Problems of Economics and Management (pp. 11-17). Lviv: Lviv Polytechnics, National University.

Becker, G. (1993). Human capital: theoretical and empirical analysis, with special reference to education (3rd ed.). University of Chicago Press.

https://doi.org/10.7208/chicago/9780226041223.001.0001

Bell, D. (1999). The coming of post-industrial society: a venture in social forecasting (507 p.). Publisher: Basic books, Perseus Book Group.

Bhagwati, J. (1998). A stream of windows: Unsettling reflections on trade, immigration, and democracy. Cambridge, Mass: MIT Press.

Bohning, W. (1977). Compensating countries of origin for the outmigration of their people. World Employment Programme, Working paper. Geneva: ILO.

Capitalism, Short-terminism, Population and the Destruction of the Planet - A Report to the Club of Rome. (2018). http://filipmalinowski.net/Club_Of_Rome-report-2018_ComeOn.pdf

Corejova, T., Kassiri, M. (2016, 5-6 October). M. knowledge triangle, innovation performance and global value chain. In Proceedings of the 16th International Scientific Conference Globalization and Its Socio-Economic Consequences (pp. 329-336). Rajecké Teplice, Slovakia.

Desai, M., Kapur, D., \& Mchale, J. (2003). The Fiscal impact of high skilled emigration: flows of Indians to the U.S. Harvard University: Harvard. 
Dewi, Yu., Dwiatmadja, Chr., Suharti, L. (2019). A qualitative study on learning organization as an essential action lowering skill mismatch effects. Business: Theory and Practice, 20, 50-60. https://doi.org/10.3846/btp.2019.05

Europa 2020. (2010, 3 March). A strategy for smart, sustainable and inclusive growth. Communication from the Commission, Brussels. http://eur-lex.europa.eu/legal-content/EN/TXT/PD $\mathrm{F} /$ ?uri=CELEX:52010DC2020\&from $=\mathrm{EN}$

Fedulova, L. I. (2008). Conceptual foundations of the knowledge economy. Economic Theory: Scientific Journal, 2, 37-59.

Geddes, A. (2005). Immigration and Welfare State. International migration and security: opportunities and challenges. London; New York: Routledge.

Gladka, O., \& Fedorova, V. (2019). Defining personnel marketing strategies. Business: Theory And Practice, 20, 146-157. https://doi.org/10.3846/btp.2019.14

International organization for migration. (2016). Migration as a factor of development of Ukraine. Research of financial income related to migration and its impact on the development of Ukraine http://www.iom.org.ua/sites/default/files/mom_migraciya_yak_chynnyk_rozvytku_v _ukrayini.pdf

Jain, S. (2013). For love and money: second-generation IndianAmericans "return" to India. Ethnic and Racial Studies, 36(5), 896-914. https://www.deepdyve.com/lp/taylor-francis/forlove-and-money-second-generation-indian-americans-return-to-india-rHT07adnCp

Katseli, L., Lucas, R., \& Xenogiani, T. (2006). Effects of migration on sending countries: what do we know. Working paper No. 250. Paris: OECD Development Centre.

Kendrick, J. (1976). The formation and stocks of total capital. New York, N.Y.: Columbia University Press for NBER.

Kraay, A. (2018). Methodology for a World Bank human capital index. Technical report, World Bank Policy Research Working Paper, No. WPS8593, 1.

https://doi.org/10.1596/1813-9450-8593

gov.ua (2017). Labor migration is one of the biggest threats to the state. Government Portal. https://www.kmu.gov.ua/ua/news/ trudova-migraciya-odna-z-najbilshih-zagroz-dlya-derzhavigennadij-zubko

Legrain, Ph. (2016). Refugees work: a humanitarian investment that yields economic dividends. https://static1.squarespace. com/static/55462dd8eb0a65de4f3a087/t/573cb9e8ab48de57 372771e6/1463597545986/Tent-Open-Refugees+Work_VFINAL-singlepages.pdf

List, J., \& Rasul, I. (2010). Field experiments in labor economics. Working paper No. 16062. Cambridge: National Bureau of Economic Research. https://doi.org/10.3386/w16062

Machlup, F. (1962). The production and distribution of knowledge in the United States (401 p.). Princeton: Princeton University Press. http://books.google.com.ua/books/ about/The_Production_and-_Distribution_of_Knowl. html?id=kp6vswpmpjoC\&redir_esc $=y$

Manuti, de Palma, P. D. (2014). Why human capital is important for organizations: people come first (1st ed.) (p. 198). Palgrave Macmillan: London, UK. https://doi.org/10.1057/9781137410801

Massey, D. (1998). Worlds in motion: understanding international migration at the end of the millennium. Oxford: Oxford University Press.

Migration and remittances Factbook. (2011). World Bank (p. 249).

Mincer, J. (1974). Schooling, experience, and earnings. Columbia University Press.
Papademetriou, D. G., Sumption, M., \& Somerville, W. (2009). Migration and the economic downturn: what to expect in the European Union. Washington DC: Migration Policy Institute.

Pekar V. (2012). Human Capital of Ukraine 2025. Results of foresight. http://wikicitynomica.org/future/lyudskiy-kapitalukraini-2025- pidsumki-forsaytu.html

Podra, O. P. (2019). Development of the investment mechanism for the human capital reproduction under conditions of the information society. Social-law Studios, 3(5), 58-66.

Proshak, G. V. (2008). The main components of human capital: theoretical aspect. Scientific Bulletin of NLTU Ukraine, 18(4), 305-309.

Putnam, R. (2000). Bowling alone: the collapse and revival of American community. N.Y.: Simon and Schuster. https://doi.org/10.1145/358916.361990

Radionova, I. F. (2009). Economic growth with the participation of human capital. Economy of Ukraine, (1), 19-30.

Romanova, A. S., Kovalchuk, V. B., Savenko, V. V., Yevkhutich, I. M., \& Podra, O. P. (2019). Financial and Credit Activities: Problems of Theory and Practice, 30(3), 490-500. https://doi.org/10.18371/fcaptp.v3i30.179925

Schultz, T. (1971). Investment in human capital: the role of education and of research. N.Y.

Sciavo-Campo, S., \& Sundaram Pachampet, S. (2001). To serve and to preserve: improving public administration in a competitive world (p. 533). Manila: Asian Development Bank.

Sen, A. (1999). Development as freedom. New York: Oxford University Press.

Simon, J. (1990). Population matters: people, resources, environment, immigration. New Brunswick, New Jersey: Transaction Press.

Solow, R. M. (1990). The labor market as a social institution. Blackwell.

Stark, O. (1991). The migration of labour. Cambridge: Basil Blackwell.

Taylor, J. (1996). International migration and economic development: a micro economy-wide analysis. Development strategy, employment and migration: insights from models. Paris: Organization for Economic Cooperation and Development.

The Law of Ukraine "On foreign labour migration. (2015). http:// w1.c1.rada.gov.ua/pls/zweb2/webproc34?id=\&pf3511=55975 \&pf35401 $=36234$

The club of Rome. (2018). A finer future. Creating an ecinomy in service to life. A Report to the Club of Rome. https://www.clubofrome.org/report/a-finer-future

Thurow, L. C. (1970). Investment in human capital. Wadsworth series in labor economics and industrial relations. California, Belmont: Wadsworth Publishing Company, Inc.

Vovkanych, S., \& Semiv, L. (2007). Theoretical and methodological foundations of the study of human and intellectual capital in knowledge-intensive economy: conceptualization of concepts. Regional Economics, (4), 7-18.

Walmsley, T., \& Winters, L. (2000). Relaxing the restrictions on the temporary movements of natural persons: a simulation analysis (Discussion Paper No. 3719). London: Centre for Economic Policy Research.

Zakharova, O. V. (2010). Managing investment in human capital: methodology, evaluation, planning: monograph (378 p.). Donetsk: DVNZ DonNTU.

Zand, R. (2000). Technopoles of India? http://webcache.googleusercontent.com/search?q=cache: http://www.robzand.com/media/technopoles.pdf\&gws_ $\mathrm{rd}=\mathrm{cr} \& \mathrm{ei}=\mathrm{ueKWWdS2AsLC6QTtkYbABQ}$ 